\title{
PNOC Gene Product
}

National Cancer Institute

\section{Source}

National Cancer Institute. PNOC Gene Product. NCI Thesaurus. Code C118221.

A protein encoded by the PNOC gene. 